\title{
CZECH TAX HEAVEN FOR SPORTSMEN
}

\author{
MICHAL RADVAN
}

\begin{abstract}
There is no specific legal regulation of professional athletes in the Czech Republic. In practice, both individual players and team players are mostly self-employment. In case of team players, compared to the legal regulation in other European countries, it is unique. This article deals with the legal regulation of professional team players, especially in the area of taxation. It works with the hypothesis, stated in two judgments of the Supreme Administrative Court, that team players should tax their incomes by the personal incomes tax as self-employed persons, i.e. businesspersons. In 2011, the Supreme Administrative Court stated that team players are not employees of their club and they should pay taxes as from independent activities. The Czech Financial Administration followed this decision and taxed these sportsmen as so-called independent professions. The reason why the Supreme Administrative Court reopened this issue was the case of football player David Lafata, who got a business license (he became a businessperson) as a footballer and claimed that playing football is not an independent profession, but real business. The aim of the paper is to confirm or disprove the hypothesis stated above, analyzing existing legal regulation and case law, and it offers solutions de lege ferenda.
\end{abstract}

\section{Keywords}

Tax; tax law; personal income tax, sportsman

\section{JEL Classification: H24, K34, Z20}

$1 \quad$ Michal Radvan is vice-dean for foreign and external affairs at the Faculty of Law, Masaryk University, Czech Republic, and Associate Professor of Financial Law at the Department of Financial Law and Economics. He specializes in tax law. He is the author of 5 books and the coauthor of almost 45 books. He presented his scientific research in approx. 80 reviewed articles in prestigious journals and conference proceedings. He is a member of the European Association of Tax Law Professors and the Information and Organization Centre for the Research on the Public Finances and Tax Law in the Countries of Central and Eastern Europe. Contact email: michal.radvan@law.muni.cz. 


\section{Introduction}

Sport is an international phenomenon. Sportsmen are moving from one place to another, from one state to another. There is no obstacle to show sporting performance in different places all over the world. Not only individual sportsmen but also team players can earn money by sports activities in different countries and can play for different clubs. In the economic sense of view, it is only a question of supply and demand.

As all sportsmen know, the sports career is relatively short (with the exemption of unique cases like Czech ice hockey player Jaromír Jágr, who is still active in his 45 years playing NHL) and it is necessary to earn enough money to be financially secure for the sports pension. It is crucial to have not only high brut income (what is comparable in all states where the particular sport is popular, with regard to the economic consequences in individual countries) but especially net income, after taxation. This might be an area for tax competition between states. During the last year, we could see many football players moving to two most traditional Czech football clubs Sparta and Slavia. Sparta Prague has signed e.g. Jonathan Biabiany from Inter Milan, Rio Mavuba from Lille OSC, Georges Mandjeck from FC Metz, Semih Kaya from Galatasaray SK, Srdjan Plavšić from FK Crvena Zvezda, Tal Ben Chaim from Maccabi Tel-Aviv, Marc Janko from FC Basel. New players in Slavia Prague are e.g. Tomáš Necid from Bursaspor, Miroslav Stoch from Fenerbahçe SK, Eduard Sobol from Sachtar Doneck, Ruslan Rotaň from Dnepr Dnepropetrovsk, Halil Altintop from FC Augsburg, and Danny from Zenit St. Petersburg. What are their reasons to play in the Czech football league, what is definitely not a prestigious destination compared to Spanish La Liga, Premier League in the UK, German Bundesliga, French Ligue 1 or Italian Serie A? Maybe they want to be a part of a new project to create prestigious European club, maybe they want to live in beautiful and historical Prague, maybe they like Czech girls... or maybe they want to earn good money.

Compared to other European countries, assuming that the brut income would be the same in other countries, the Czech Republic offers better net income. There is no specific legal regulation of professional athletes in the Czech Republic. In practice, both individual players and team players are mostly self-employment. In case of team players, compared to the legal regulation in other European countries, it is unique. This article deals with the legal regulation of professional team players, especially in the area of taxation. It works with the hypothesis, stated in two judgments of the Supreme Administrative Court, that team players should tax their incomes by the personal incomes tax as self-employed persons, i.e. businesspersons. In 2011, the Supreme Administrative Court stated that team players are not employees of 
their club and they should pay taxes as from independent activities. The Czech Financial Administration followed this decision and taxed these sportsmen as socalled independent professions. The reason why the Supreme Administrative Court reopened this issue was the case of football player David Lafata, who got a business license (he became a businessperson) as a footballer and claimed that playing football is not an independent profession, but real business. In both cases, the personal income tax base is created as the difference between income and expenditure. As mostly there are no real high expenditures, Czech legal regulation allows the lump sum expenses: in case of the independent profession $40 \%$, but for business (in this very case) 60\%. The aim of the paper is to confirm or disprove the hypothesis stated above, analyzing existing legal regulation and case law and comparing different approaches of sportsmen taxation. Using the synthetic method, the article offers solutions de lege ferenda.

The existing scientific literature in given area in the Czech Republic is not important at all, it is mostly descriptive (Sluka, 2007) or focused on case law (Vybíral, 2013). The existing legal regulation and case law before the Lafata case were described by Radvan and Neckár (2016) and this paper is partially used in this text (mainly chapters 2 and 5). International scientific literature is at a higher level; there should be mentioned publications by Tetłak (2014), Simpson (2012), or book edited by Loukota and Stefaner (2007).

\section{Individual Sportsmen vs. Team Player}

Individual professional athlete (i.e. tennis player, boxer etc.) mostly (let us disregard team competitions in team sports, e.g. Davis Cup, Fed Cup) acts on his/her behalf and on his/her responsibility. S/he chooses which tournaments to play, during the year $\mathrm{s}$ /he is paid by several subjects (usually by the organizer of a sports event), s/ he bears the costs for a coach, massage therapists, servicemen and other persons in his/her team, s/he chooses when and where s/he trains, etc. (Radvan, Neckár, 2016).

The performance of a team player is highly determined by club rules and regulations in which his/her activity is performed. Team players (typically ice hockey, football, basketball, volleyball players etc.) are in a relationship only with one subject - the club, in which they perform their activity. They do not act on their behalf nor on their own responsibility but only as members of a team or a club. It is also the leadership of the club who determines all duties of its functioning, whether it is the placement in a specific competition (transfer the player during the season with or without the player's consent), training, following the regimen and other individual aspects of its activity. The club itself hires coaches and the whole service team, whereas the player cannot influence it whatsoever. Team players must abide by obligations set 
forth by the leadership and their coaches. It is a paradox that the higher the level of sports activity of a certain club, the higher is the amount of dependence of player's activity on the club (Radvan, Neckár, 2016).

In many European countries, it is quite common that team players are employees of the club. In the Czech Republic, however, professional team players are selfemployed. The player and the club conclude a so-called professional contract, which is considered to be an innominate contract in the Czech legal order (Civil Code, Art. 1746/2). Professional contracts include mutual rights and obligations of the player and the club. Some kind of a model contract is included in the Directive on the evidence of professional and non-amateur contracts (Fotbal.cz, 2014) approved by the Executive Committee of the Football Association of the Czech Republic. It is a paradox that the first article states that "in accordance with the professional contract the player performs the sports activity as his main employment", which means a dependent activity. However, according to the model professional contract in football (Vybíral, 2013: 13) "in the area of income tax, social and health security, the player is considered to be self-employed in accordance with of the Income Tax Act and his income arising from this contract is the income from independent employment which is neither a profession based on a license nor entrepreneurship under special regulations". It is necessary to add that similar contracts are concluded in other team sports; however, any provision of this type in a private contract is for the purpose of public tax law irrelevant (Radvan, Neckár, 2016).

It is apparent that the activity of a professional team player is specific and it is not, therefore, possible to apply without limitations all institutes of labor law guaranteed by the Labor Act. The main aspect, which is the object of disputes between the advocates of employment relationships of athletes and sports clubs, is the possibility of a one-way termination of the employee (the player) without giving any reason; in this case, a player could change clubs without any compensation. We can also state the problem of working hours, overtime and obligatory breaks at work as well as limitations set for the conclusion of fixed-term employment contracts. According to effective legal norms, it is possible to prolong an employment agreement only twice; shall it be prolonged one more time, the employment contract must be concluded for the indefinite time (Radvan, Neckár, 2016).

\section{Tax Issues}

The reason why is the problem of taxation of team player's income repeatedly discussed is the different rate of income taxation in case the athlete taxes his/her income as an income from employment or s/he taxes it as an income from selfemployment. The fact that team players consider themselves as self-employed is 
from the established practice, which is considered favorable not only for themselves but also for the clubs. Athletes receive an unreduced fee and it is their obligation to fill out a tax return and pay taxes as well as social and health security. This obligation is therefore not on the club. This also enables the players to deduct from their incomes costs, which they spend in accordance with their activity. This is not possible with the taxation of employees. Costs spent to reach, secure and maintain incomes, players include for example the washing of uniforms (even though it is done via the club), the cost for travels to European cup matches, diet costs, accommodation, trips to training, etc. Jiří Sabou, not very well known exfootball player of Žižkov and Teplice, stated among his costs a fee for his agent who was supposed to negotiate contracts for him in Manchester United, FC Barcelona, Olympique Marseille or AC Monaco even though none of these teams knew nothing about this average Czech football player. This whole matter was addressed by the European Court of Justice in Luxembourg (ECJ: no. C-276/12) (Radvan, Neckár, 2016).

In terms of taxation of team players' income, the terms which set up the relationship between the player and the club are not essential. It is necessary to determine the characteristics of the player's activity and its subordination under particular provisions of the Income Tax Act. Two basic types of incomes come to mind income from employment and income from self-employment. The main difference is the construction of the tax base.

In case of self-employed sportsmen, the tax base construction is the typical one: the income is reduced by expenditures (costs) necessary to reach the income. Because team players usually do not have high expenditures (the club pays most costs), they are applying so-called lump sum expenses. These lump sum expenses can be $60 \%$ of the income if the sportsman runs a trade, respectively $40 \%$ in case of the independent profession. The maximum amount of the lump sum expenses to be applied in 2016 is CZK 1,200.000 for trade and CZK 800,000 for the independent profession. It must be noted that tax preferences for children and tax relief for the spouse cannot be used as lump sum expenses are applied. On the other hand, the spouse can use tax preferences for children and basic tax relief to lower the family taxation. For the taxable period 2018, the maximum amount of lump sum expenses is lowered to CZK 600,000 for trade, respectively CZK 400,000 for the independent profession, and tax preferences for children and tax relief for the spouse can be applied without any limitations. For the taxable period 2017, the taxpayer has right to choose the regulation valid in 2016 or in 2018 , depending on his/her personal circumstances.

In case of dependent activity (employed sportsman), the super gross wage as a tax base is used. Such a construction is unique in the whole world. Super gross wage 
is a gross wage increased by $34 \%$ of the gross wage as sums of social security insurance premium, contribution to the state employment policy and general health insurance premium that must be paid by the employer. If we accept the social security premiums (or at least social security insurance premium) as taxes, we can talk about the tax on tax, i.e. double taxation.

\section{Case Law}

Until 2011, there was no decision of Czech courts dealing with the taxation of professional team players' incomes. In practice, almost no team players were employed by their clubs. The first ruling was issued in 2011 by the Supreme Administrative Court (2 Afs 16/2011-78). The Court stated that "Even though the activity of professional athletes, although not expressly excluded from entrepreneurship by the Trade Licensing Act, cannot be subordinated under permitted, professional or unqualified trade and neither is an independent profession, many athletes, as well as sports clubs, consider relations arising out of the so-called professional contracts to be of self-employed nature and incomes arising out of these contracts are to be considered as incomes from self-employment".

The Court examined the activity of a professional ice hockey player and concluded that "the activity of a professional athlete cannot be easily subordinated under "employment" in the sense of Labor Act. It cannot be therefore excluded, respectively considered illegal the conclusion of other than labor contracts between players and their clubs". It is disputable, whether it is necessary to interpret the term "employment" and forget to deal with the similar but tax term "employment". This simplification then leads to a faulty conclusion of the Court, which states: "... it is generally accepted in practice that professional athlete may - from a tax point of view - act as self-employed ... To divert from this generally accepted practice, there would have to exist a very strong reason based on for example an explicit change of the legal norms. Otherwise, it is possible to argue by way of certain level of normative power of facticity" (Radvan, Neckár, 2016).

I find this conclusion wrong. Primarily most of the arguments are dealing with the relation between the club and the sportsman from the civil law perspectives. It is apparent that the activity of a professional team player is specific and it is not, therefore, possible to apply without limitations all institutes of labor law guaranteed by the Labor Act. However, in terms of taxation of team players' income, the terms which set up the relationship between the player and the club are not essential. It is necessary to determine the characteristics of the player's activity and its subordination under particular provisions of the Income Tax Act. Moreover, the 
fact that something is happening illegally for a longer period cannot mean that this behavior shall become in accordance with the law.

Czech tax administration, unfortunately, started following the ruling of the Supreme Administrative Court. Team players were taxed as an independent profession, even this term is not defined in Czech law, was never defined by the courts and legal science has never created any definition. Mostly it is accepted that independent profession includes artists. In July 2017 the Supreme Administrative Court in Lafata case (6 Afs 278/2016-54) stated that "the independent activity of a professional athlete can be performed either as a trade or as an independent profession. If the tax subject carries out the activity of a professional football player as a trade on the basis of the relevant trade license, the income from this activity represents income from the trade." I.e. the 60\% lump sum expenses (and not only 40\%) can be applied. Most of the arguments of the Court are connected with the definition of trade: the activity carried out on a continuous basis, independently, on own behalf, on own responsibility, and in order to obtain a profit. The Court stated that some characters (independence, own behalf, and own responsibility) are suppressed, but still decided that the independent activity of a professional athlete can be performed as a trade.

I do agree with the decision that the activity of a professional team player is not an independent profession. However, definitely, it is not a trade, too. The characters of trade are not only suppressed; they are simply not there at all. The Supreme Administrative Court missed the possibility to reopen the issue of team players' taxation from dependent activities and missed the opportunity to change existing unreasonable and unjustifiable practice.

\section{Conclusions}

Certainly, team players do not perform on their behalf and do not make independent decisions. Their income received from the clubs (whether it is for individual matches, in the form of a regular fee for sport or other performance in favor of the club) cannot be considered as income from self-employment (business/trade/ independent profession). The taxpayer is not entitled to reduce this income of the relevant costs spent to reach, secure and maintain incomes as well as $\mathrm{s} / \mathrm{he}$ is not entitled to apply lump costs. However, income from for example advertising activities of the individual player that are not connected with his/her activity for the club could be taxed as an income from self-employment (Radvan, Neckář, 2016).

Income from employment includes payment in the form of an income from present or past employment and similar relationships, in which the taxpayer performing the activity for the employer must oblige orders of the employer. In 2005, the Supreme 
Administrative Court dealt with these terms with the emphasis on the nature of a relationship similar to employment and similar relationships (2 Afs 176/2004-140). It stated that a "similar relationship is a relationship which is not the employment and similar relationships, but which in its nature and role responds to the stated relationships, that means that its main characteristics are the same as with these relationships. Common to employment and similar relationships are first that it is a legal relationship, usually of a private nature but also of a public nature (typically an official relationship)..." When examining whether the given relationship can be subordinated under the term "similar relationship", it is always necessary to examine its actual content intended and wanted by the participants especially if the participants pretend something different than what is the actual content of their legal relationship. The Court emphasized the principle of material justice, respectively the principle of content priority. "When closing the so-called professional contract, it is not important what the title of the contract is and under which legal provisions it was made but what is its content and what are the rights and obligations of the parties" (Radvan, Neckáŕ, 2016).

Another important feature of employment and similar relationships considered by the Supreme Administrative Court is that this relationship is of a long-term character, which is determined by the fact that it is not consumed on a one-time basis by fulfilling a certain obligation. So-called professional contracts also fulfill this definition since they are often concluded for the term of one to five years (Radvan, Neckář, 2016).

Another significant feature of employment and similar relationships not only considered by the Supreme Administrative Court is the fact that the person who provides a certain performance is obliged to follow orders of the person to whom $\mathrm{s} /$ he is bound by the employment and similar relationship. This obligation must be made directly, i.e. it must be the content of the legal relationship between both participants. For example, under the model professional contract, a football player is obliged to fulfill assignments and orders of coaches during training, at training camps and of course during matches (Vybíral, 2013: 12-17). For his performance, the player receives a fee, usually money (Radvan, Neckár, 2016).

It is without a doubt that the so-called professional contracts in the area of team sports fulfill cumulatively all signs of a relationship similar to an employment and other similar relationships and therefore team players' income should be taxed as income from employment (Radvan, Neckář, 2016).

The term "dependent activity" was determined by the Supreme Administrative Court in its previous ruling (2 Afs 62/2004-70). It stated that in order to be considered as a "dependent activity" a person cannot only perform an activity according to relevant 
orders but it must be an activity truly dependent on the employer. Definition of dependency shall be given by the nature of the performed activity (typically an activity performed at one place exclusively for one employer). It shall also be a longterm activity and the employment relationship shall be made in favor of the person performing the activity. It is also important to note that athletes do not perform their activities in one place. However, it is necessary to consider the text of this ruling a bit inaccurate and wrong since undoubtedly many more activities exist with noticeable worker mobility. On the other hand, it is necessary to emphasize the part talking about one employer. Especially with team players, it is unimaginable that for example an ice hockey player or football player would play in one round of a long-term competition in more than one match for one club (Radvan, Neckár., 2016).

Incomes of team players received from the club are undoubtedly incomes taxed as income from employment because the relationship between the player and the club cumulatively fulfills all signs of a relationship similar to employment and other similar relationships. The hypothesis stated in two judgments of the Supreme Administrative Court that team players should tax their incomes by the personal incomes tax as self-employed persons, i.e. businesspersons, was disproved. Until the courts change their incorrect opinion or until the amendment of de lege lata regulation (so that the courts cannot insist on their incorrect case law), the Czech Republic remains a tax haven for professional team players and a specific island not only in Europe, where the incomes from club are taxed as business incomes and not as incomes from dependent activities, i.e. much less than in other countries.

\section{References}

Loukota, W., Stefaner, M.C. (eds.): Taxation of Artistes and Sportsmen in International Tax Law, Vienna: Linde Verlag, 2007.

Radvan, M., Neckář, J.: Taxation of Professional Team Sports Athletes in the Czech Republic, Public Governance, Administration and Finances Law Review in the European Union and Central and Eastern Europe no. 1 (2016).

Simpson, A.: Taxation of Non-Resident Entertainers and Sportsmen: The United Kingdom's Definition of Performance Income and How it Ought to be Measured, Washington University Global Studies Law Review no. 11 (2012).

Sluka, T.: Profesionální sportovec: právní a ekonomické aspekty (Professional Sportsman: Legal and Economic Aspects), Praha: Havlíček Brain Team, 2007.

Tetłak, K.: Taxation of International Sportsmen, Amsterdam: IBFD, 2014.

Vybíral, R.: Analýza judikatury vztahující se $\mathrm{k}$ postavení profesionálních sportovců $\mathrm{v}$ oblasti kolektivních sportů v České republice (The Analysis of the Case Law Relating to the Status of Professional Athletes in Team Sports in the Czech Republic), Jurisprudence no. 1 (2013). 


\section{Michal Radvan}

Directive on the evidence of professional and non-amateur contracts, 2014. www.fotbal.cz.

EU: ECJ: C-276/12 (Jiri Sabou v. Financial Directorate Prague).

CZ: Supreme Administrative Court: 2 Afs 62/2004-70.

CZ: Supreme Administrative Court: 2 Afs 176/2004-140.

CZ: Supreme Administrative Court: 2 Afs 16/2011-78.

CZ: Supreme Administrative Court: 6 Afs 278/2016-54. 